\title{
Pendidikan dayah di Aceh dalam bayang-bayang pandemi Covid-19
}

\author{
Abidah' ${ }^{1}$, Ahmad Khusairi' \\ STAIN Teungku Dirundeng, Meulaboh ${ }^{1}$ \\ Universitas Islam Negeri Ar-Raniry Banda Aceh ${ }^{2}$ \\ abidah8383@gmail.com ${ }^{1}$
}

\begin{abstract}
Dayah as an Islamic educational institution has a great influence on the lives of the people of Aceh in particular and Indonesia to date. People still pay great attention to dayah as an alternative education. In general, dayah education aims to foster people to have good personalities following Islamic teachings and instil a religious sense in all aspects of life. This study aims to look at the role of the dayah during the covid-19 pandemic (a case study in the Istiqamatuddin dayah in Lamceu Village, Aceh Besar). The type of research determined is descriptive qualitative using interviews and observations of educational activities in dayah during the Covid-19 pandemic. The results showed that the learning process at the dayah continued as usual but by implementing strict health protocols (prokes). Bandongan and sorogan methods are methods used in the learning process. This is done to increase the motivation and interest of the students in studying at the dayah. In addition, studying at the dayah for santri helps them prevent boredom of studying online at home during the pandemic.
\end{abstract}

Keywords: Dayah, Education, Pandemic Covid-19.

\begin{abstract}
Abstrak
Dayah sebagai lembaga pendidikan Islam memiliki pengaruh besar dalam kehidupan masyarakat Aceh khususnya dan Indonesia sampai saat ini. Masyarakat masih menaruh perhatian besar terhadap dayah sebagai pendidikan alternatif. Secara umum, pendidikan dayah bertujuan membina masyarakat agar berkepribadian baik sesuai dengan ajaran-ajaran Islam dan menanamkan rasa keagamaan pada semua segi kehidupan. Penelitian ini bertujuan untuk melihat peran dayah selama masa pandemi covid-19 (studi kasus di dayah Istiqamatuddin Desa Lamceu, Aceh Besar). Jenis penelitian yang ditetapkan adalah kualitatif deskriptif dengan menggunakan wawancara dan observasi terhadap kegiatan pendidikan di dayah selama masa pandemi Covid-19. Hasil penelitian menunjukkan bahwa proses pembelajaran di dayah tetap berlangsung seperti biasa namun dengan menjalankan protokol kesehatan (prokes) yang ketat. Metode bandongan dan sorogan merupakan metode yang digunakan dalam proses pembelajarannya. Hal ini dilakukan agar menambah motivasi dan minat para santri dalam menuntut ilmu di dayah. Selain itu, belajar di dayah bagi santri sangat membantu mereka mencegah kebosanan belajar daring di rumah selama masa pandemi.
\end{abstract}

Kata kunci: Dayah, Pendidikan, Pandemi Covid-19. 


\section{A. Pendahuluan}

Sejak 2019 dunia digemparkan dengan wabah pandemi Covid-19 atau yang dikenal dengan coronavirus disease. 30 Januari 2020, WHO telah menetapkan sebagai kedaruratan kesehatan masyarakat yang meresahkan dunia. Pada tanggal 2 Maret 2020, Indonesia melaporkan kasus konfirmasi Covid-19 sebanyak 2 kasus. Sampai dengan tanggal 16 Maret 2020 ada 10 orang yang dinyatakan positif corona (Yurianto \& Wibowo, 2020). Dengan adanya virus Covid-19 di Indonesia saat ini berdampak bagi seluruh masyarakat, seperti sosial, ekonomi, pariwisata dan pendidikan.

24 maret 2020 Menteri Pendidikan dan Kebudayaan Republik Indonesia mengeluarkan Surat Edaran Nomor 4 Tahun 2020 Tentang Pelaksanaan Kebijakan Pendidikan Dalam Masa Darurat Penyebaran Covid, dalam Surat Edaran tersebut dijelaskan bahwa proses belajar dilaksanakan di rumah melalui pembelajaran daring (jarak jauh). Hal tersebut dilaksanakan untuk memberikan pengalaman belajar yang bermakna bagi siswa (Indonesia, 2021). Belajar di rumah dapat difokuskan pada pendidikan kecakapan hidup antara lain mengenai pandemi Covid-19, protokol kesehatan dan kegiatankegiatan bermanfaat lainnya. Dengan kondisi demikian, untuk mencegah kebosanan belajar daring di rumah, anak-anak sekolah di sebagian tempat juga mengisi waktunya dengan belajar mengaji di dayah, seperti halnya anak-anak yang tinggal di Desa Lamceu yang memilih mengaji di dayah Istiqamatuddin Desa Lamceu.

Dayah dan Balai Pengajian merupakan lembaga pendidikan Islam tertua di Aceh yang telah lama berkiprah dalam membangun sumber daya manusia (SDM). Pada permulaannya kegiatan belajar-mengajar ini hanya berlangsung di rangkang-rangkang, dengan pelajaran utamanya terfokus pada pelajaran agama dan mengajarkan kitab-kitab Arab tertentu yang telah di tetapkan oleh pengasuh (Indonesia D. A., 2004).

Keberadaan Dayah dan Balai Pengajian tidak terlepas dari kegiatan pengajaran dan dakwah Islam. Kegiatan pengajaran dan dakwah seperti ini 
masih terus berlangsung sampai sekarang, bahkan jumlahnya pun turut bertambah seiring bertambahnya penduduk. Demikian pula halnya rasa ketertarikan untuk mempelajari agamanya lebih baik, dimana Dayah merupakan tempat para generasi Islam dibekali dengan ilmu pengetahuan agama dan pengetahuan lainnya (Pemahaman pendidikan Islam). Peran lembaga pendidikan Dayah dan Balai Pengajian semakin dibutuhkan dalam usaha membentuk pola pikir umat, terutama untuk mendekatkan manusia dengan Islam itu sendiri (Hamidansyah, 2011).

Eksistensi dayah khususnya di Aceh telah ada semenjak kesultanan dan turut mewarnai kehidupan masyarakat secara menyeluruh dan memainkan fungsi sosial, khususnya dalam disiplin ilmu agama. Masyarakat Aceh terutama anak-anak mudanya kebanyakan meudagang, merantau untuk mendapatkan bekal pengetahuan (Latif, 2007). Dengan orientasi tersebut, dayah atau pondok pesantren di Aceh telah mampu menunjukkan partisipasi aktifnya bersama-sama elemen masyarakat termasuk pemerintah dalam menyukseskan program-program pembangunan, terlebih dalam hal kehidupan keagamaan dan pencerdasan anak bangsa. Pergulatan literatur sejarah dan dinamika sosial secara dialektik membuat dayah mempunyai kesadaran dan konsen untuk ikut mengawasi proses perjalanan bangsa sesuai dengan cita-cita agama dan masyarakat secara universal.

Dayah adalah lembaga pendidikan di Aceh yang dipimpin oleh seorang ulama. Dayah merupakan lembaga pendidikan yang mengajarkan ilmu-ilmu keislaman, seperti tauhid, fikih dan tasawuf (Shahrizal, 2007). Uraian tentang dayah ini memiliki relevansi dengan kegiatan dakwah yang melakukan usahausaha penyiaran (menyiarkan) agama Islam. Keberadaan dayah dalam konteks masa kini juga perlu dipikirkan bahwa dayah memiliki multifungsi hal-hal positif yang dapat digunakan sebagai alat dalam proses pembangunan masyarakat dan penguatan kapasitas masyarakat. Dayah juga merupakan tempat cikal bakal lahirnya generasi pemimpin di dalam masyarakat. Sebagaimana kita ketahui, bahwa salah satu faktor yang mempengaruhi maju 
dan berkembangnya sebuah dayah adalah adanya kekuatan dari unsur kefiguran/ketokohan atau biasa disebut dengan istilah teungku (Aurora , 2012).

Selain itu, sebutan untuk teungku di Aceh dapat dikelompokkan kepada dua yaitu, teungku tradisional (yang berlatar belakang pendidikan dayah) dan teungku pembaharu (yang berlatar pendidikan bukan dayah). Kemudian kepada mereka mendapat sebutan Abu, Abi, Abon, Walid, Tu, Buya dan Abuya. Sebutan-sebutan tersebut sering diletakkan kepada teungku dayah (alumni dayah salafi). Sedangkan sebutan ustad, ayah, bapak dialamatkan kepada teungku pembaharu (bukan dayah). Untuk sebutan teungku (berasal dari tuanku) dan teungku haji (sebutan bagi teungku yang sudah menjalankan rukun Islam ke lima) (Saby, 2000).

Lembaga-lembaga seperti dayah yang menghasilkan teungku semakin minim, jika tidak boleh dikatakan sirna sama sekali. Dahulu, dayah merupakan lembaga pendidikan yang mampu menghasilkan teungku yang disegani. Dalam hal ini, peran dayah menjadi titik sentral dalam membangun jaringan keteungkuan di Aceh. Tanpa dayah, maka sulit menemukan teungku yang mampu menguasai tradisi klasik, meskipun sekarang lembaga dayah sudah menjadi pilihan kedua bagi orang tua dalam mendidik anak (Ahmad., 2003).

Peran teungku dan gerakan organisasi yang didirikan oleh teungku di Aceh sampai hari ini masih menarik untuk diteliti, meskipun pemikiran mereka saat ini tidak ada yang benar-benar baru bagi masyarakat, namun karena konsistensi mereka dalam menjalankan peran dinamisnya kepada masyarakat menyebabkan teungku selalu diistimewakan oleh masyarakat Aceh (Sufi, 2002).

Selain itu, lembaga pendidikan Dayah juga berfungsi sebagai wadah pemrakarsa peran sosial dalam masyarakat. Fungsi Dayah juga ditunjukkan bila terjadi suatu musibah kematian atau musibah dalam bentuk lain. Masyarakat lebih mempercayakan urusannya kepada orang-orang Dayah, bahkan dibandingkan dirinya sendiri. Sebagai lembaga yang mengakomodir 
kebutuhan pendidikan masyarakat secara luas, Dayah dan Balai Pengajian, perlu mendapat perhatian untuk didalangi secara terstruktur dalam suatu pemerintahan untuk mewujudkan misi keislaman melalui transmisi ilmu pengetahuan keislaman sebagai wadah pembentukan pribadi muslim agar dapat menjalankan mandate sebagai hamba sekaligus khalifah Allah untuk menyejahterakan kehidupan di muka bumi (Azra, 2009).

Adapun Balai Pengajian dimaksudkan pada lembaga pendidikan nonformal yang diselenggarakan dalam lingkungan masyarakat baik dilakukan secara perseorangan dengan satu penanggung jawab, (pendiri itu sendiri) maupun kerjasama para tokoh dalam gampong, 11 pendidik, aparatur gampong untuk menyelenggarakan suatu pengajian di dalam lingkungan mereka. Pengajian ini tidak terbatas usia, apakah untuk anak usia dini, remaja maupun dewasa (Undang-Undang, 2001).

Dilihat dari kiprahnya dari masa ke masa, dayah memiliki peran multifungsi, baik sebagai sarana dimana berlangsungnya aktifitas belajar mengajar maupun sebagai motor pergerakan pembentukan karakter ummat yang berhaluan keislaman yang dibarengi akhlak. Peran Dayah juga ditunjukkan pada saat pra kemerdekaan RI maupun setelah diproklamirkan kemerdekaan. Para tuan guru telah memulai mengatur strategi perjuangan dari Dayah yang disambut antusias oleh masyarakat. Fatwa-fatwa ulama yang berasal dari Dayah menjadi rujukan dan Imam bagi masyarakat, sehingga Islam di Aceh terutama menjadi seperti satu barisan yang tidak dapat dipisahkan satu sama lain.

Melihat eksistensi Dayah dan Balai Pengajian dalam masyarakat maka sangatlah beralasan untuk terus dilestarikan, bahkan semakin ditingkatkan dengan pola pengawasan bersama yang melibatkan banyak unsur yang mendukung dalam bentuk tindakan nyata. Dayah perlu melibatkan lembaga adat gampong dalam pengawasan kedisiplinan murid di lembaga pendidikan nonformal, terutama dalam mengawasi kedisiplinan belajar mereka (Rahmah, 2009). 
Kejayaan Dayah pada masa lalu telah mampu mendidik rakyat Aceh dalam berbagai hal. Sebagai hasilnya ada yang mampu menjadi raja, menteri, panglima tentera, ulama, ahli teknologi perkapalan, pertanian, perubatan, dan lain-lain. Salah satu bukti kejayaan Dayah kala itu, dapat dilihat dari peranan yang dimainkan Dayah, yaitu sebagai tempat pembangunan masyarakat, tempat penyampaian dakwah Islam (tempat belajar agama) juga sebagai tempat mendidik para santri untuk perlawanan bangsa penjajah (Amiruddin, 2004).

Keberadaan dayah sebagai lembaga pendidikan, baik yang masih mempertahankan sistem pendidikan tradisional maupun yang sudah mengalami perubahan, memiliki pengaruh besar dalam kehidupan masyarakat Indonesia. Dari waktu ke waktu dayah semakin tumbuh dan berkembang baik kualitas maupun kuantitasnya. Tidak sedikit dari masyarakat yang masih menaruh perhatian besar terhadap dayah sebagai pendidikan alternatif. Karena pendidikan dayah berkembang sampai sekarang, modelnya senantiasa selaras dengan jiwa, semangat, dan kepribadian bangsa Indonesia yang mayoritas beragama Islam. Hal ini jugalah yang dilakukan oleh dayah Istiqamatuddin Desa Lamceu, Aceh Besar. Oleh sebab itu, tujuan dari tulisan ini adalah untuk mendapatkan informasi mengenai peran yang dilakukan oleh dayah Istiqamatuddin pada masa pandemi Covid 19.

\section{B. Metode}

Penelitian ini dikategorikan sebagai penelitian deskriptif dengan pendekatan kualitatif dengan format studi lapangan (field research) (Moleong, 2009), Lokasi penelitian yaitu di Dayah Istiqamatuddin, Desa Lamceu, Aceh Besar. Observasi dan wawancara digunakan sebagai alat untuk mengumpulkan data. Setelah wawancara, hasil wawancara dianalisis dengan cara reduksi data, penyajian data, dan penarikan kesimpulan. Selain itu, kegiatan observasi juga merupakan salah satu metode pengumpulan data yang digunakan. Peneliti melakukan pengamatan terhadap kegiatan belajar di 
dayah. Observasi menggunakan model terbuka sebagai catatan lapangan untuk merekam semua fenomena yang dianggap menarik oleh pengamat. Hasil pengamatan ini dijadikan sebagai bahan pengayaan hasil penelitian yang telah diperoleh dari wawancara.

\section{Hasil dan Pembahasan}

\section{Kilas Pandang Dayah Istiqamatuddin}

Dayah Istiqamatuddin, Desa Lamceu terletak di tepi jalan raya Blang Bintang Lama, Aceh Besar. Lokasinya sangat strategis dan mudah dijangkau oleh alat transportasi. Dayah ini didirikan pada tahun 2019 oleh Tgk. H. Muhammad Abdullah Ahmad atau biasa dikenal dengan sebutan akhi. Berdirinya Dayah Istiqamatuddin ini bermula dari kesadaran para santri akhi dari malaysia dan santri sekitar akan pentingnya lembaga pendidikan nonformal yang mampu memahami kitab-kitab dasar Islam. Di samping itu, keinginan masyarakat untuk memiliki generasi penerus yang berkompeten di bidang kitab kuning menambah motivasi akhi untuk mendirikan sebuah Dayah yang memiliki dasar-dasar pemahaman hukum Islam.

Dayah Istiqamatuddin, Desa Lamceu merupakan salah satu komponen lembaga yang berjuang mendidik masyarakat dengan pendidikan secara holistik, yaitu dengan memberikan pendidikan agama maupun dengan keilmuan dan kemampuan lain agar dapat membekali santri ketika menghadapi tantangan perubahan zaman. Dayah ini sejak awal memang khusus mempelajari bidang kitab-kitab dasar dan belajar membaca Al-Qur'an. Semua santri dikonsentrasikan untuk belajar kitab, namun bagi yang belum sanggup membaca Al-Qu'an dengan baik dan benar diperkenankan juga mengaji Al-Qur'an. Pesantren ini tidak memberi batasan waktu dan usia bagi para santri, terbuka bagi pelajar, mahasiswa, ibu-ibu dan bapak-bapak yang hanya ingin berkonsentrasi belajar kitab saja. Dengan semakin berkembangnya dayah ini sekarang jumlah santri sudah mencapai 100 santri lebih, yang berasal dari beberapa desa, dan juga dari Malaysia. 
Adapun tujuan yang dipaparkan oleh Tgk.H. Muhammad Abdullah Ahmad (akhi) selaku pengasuh Dayah Istiqamatuddin, dayah ini adalah salah satu lembaga pendidikan keagamaan yang ingin berperan aktif dalam usahausaha memajukan generasi penerus bangsa. Selain itu juga bertujuan sebagai bekal para santri dalam menghadapi tantangan perubahan zaman. Hal ini dilakukan dengan memberikan pendidikan agama melalui kitab-kitab mulai dari Fiqih, akhlak, dan lain-lain dan ilmu-ilmu Al-Qur'an, terutama tata cara membaca Al-Qur'an dengan baik dan benar, yaitu mengetahui hukum-hukum bacaan Al-Qur'an (tajwid) dan fasih dalam pengucapannya.

\section{Strategi Pembelajaran Dayah Istiqamatuddin}

Adapun strategi belajar yang diterapkan dayah Istiqamatuddin dalam menghadapi masa pandemi Covid-19 berupa kegiatan-kegiatan pembelajaran yang terdiri dari: (1) materi pendidikan keislaman sesuai dengan tuntutan zaman dan kitab-kitab kuning yang digunakan di dayah, (2) adanya belajar AlQur'an, (3) adanya diskusi antara guru dan santri yang bertujuan untuk memberikan bimbingan-bimbingan.

Mengenai strategi yang diterapkan di dayah dalam menghadapi masa pandemi Covid-19 sangatlah berpengaruh terhadap kegiatan santri dalam mengisi waktu luang mereka. Hal ini sangat mendukung santri lebih giat belajar, mampu membentuk karakter yang baik, dan sadar akan tanggung jawabnya masing-masing. Salah satu komponen pendidikan yang mendukung tugas profesional guru adalah penguasaan terhadap strategi pembelajaran.

Berdasarkan hasil observasi dan wawancara yang dilakukan di dayah Istiqamatuddin menunjukkan bahwa jenis strategi pembelajaran yang digunakan di dayah ini ada dua macam, yaitu:

a) Strategi Pembelajaran Langsung

Strategi pembelajaran langsung yang terdapat di dayah Istiqamatuddin dilaksanakan ketika mengaji kitab dan pendidikan keislaman lain yang diampu oleh guru serta diberi berbagai ceramah untuk menyampaikan 
berbagai ilmu pengetahuan dari beliau.

b) Strategi Pembelajaran Interaktif

Untuk pembelajaran interaktif di dayah Istiqamatuddin ini berupa diskusi, yaitu adanya diskusi antar santri dengan santri, maupun diskusi antar santri dengan guru yang dilakukan pada saat mengaji. Hal ini bertujuan untuk melatih para santri dalam mengembangkan kompetensi belajar mereka.

\section{Metode Pembelajaran}

Dalam melaksanakan suatu strategi, penggunaan metode pengajaran menjadi salah satu unsur dalam strategi pembelajaran. Jadi metode adalah suatu cara yang digunakan untuk mencapai tujuan yang telah ditetapkan (Aqib \& Murtadlo, 2016). Metode pembelajaran adalah cara yang digunakan pendidik dalam mengadakan hubungan dengan peserta didik pada saat berlangsung pembelajaran (Sudjana, 2010). Semakin baik metode mengajar, semakin efektif pula pencapaian tujuan pengajaran.

Akhi selaku pemimpin Dayah Istiqamatuddin, Desa Lamceu berpendapat bahwa metode yang digunakan dalam pembelajaran adalah metode bandongan dan sorogan. Dalam pelaksanaannya, metode yang digunakan dalam pembelajaran adalah pembelajaran langsung yang berupa posisi guru lebih tinggi dalam proses pembelajaran. Guru membacakan, menerjemahkan, menerangkan, dan berceramah di hadapan santri. Dalam hal ini santri boleh menanyakan pelajaran yang belum faham terhadap apa yang telah diterangkan oleh guru. Selanjutnya santri mengulang bacaan dan mengaji kitab. Akhi menyatakan bahwa metode yang diterapkan di dayah sangatlah berpengaruh terhadap santri, santri lebih antusias dalam belajar dan menjadikan santri lebih baik. Dengan adanya metode bandongan dan sorogan yang diterapkan, santri sadar akan tugas dan tanggung jawabnya masingmasing. 
Metode bandongan disebut juga dengan metode wetonan. Sistem pengajaran wetonan atau bandongan di dalam dayah Istiqamatuddin berupa adanya pengajian kitab tafsir jalalin, fathul qarib, al-barzanzi, dan nashoihul 'ibad dimana pengasuh membaca sesuatu kitab dan santri membawa kitab yang sama, kemudian mereka mendengarkan dan menyimak tentang bacaan pengasuh. Metode ini juga salah satu cara yang digunakan dalam mengembangkan proses pembelajaran melalui cara penuturan.

Secara bahasa, dalam Kamus Besar Bahasa Indonesia, bandongan diartikan dengan "pengajaran dalam bentuk kelas (pada sekolah agama)" (Poerwadarminta, 1995). Sedangkan secara terminologi metode bandongan merupakan metode utama dalam sistem pengajaran di pesantren. Dalam sistem ini, sekelompok murid (antara 5-500 murid) mendengarkan seorang guru yang membaca, menerjemahkan, menerangkan dan sering mengulas buku-buku Islam dalam bahasa Arab. Setiap murid memperhatikan bukunya sendiri dan membuat catatan-catatan baik arti maupun keterangan tentang kata-kata atau buah pikiran yang sulit untuk dipahami. Kelompok kelas dari sistem bandongan ini disebut halaqah yang secara bahasa diartikan lingkaran murid, atau sekelompok siswa yang belajar di bawah bimbingan seorang guru (Dhofier, 2020).

Sedangkan untuk metode sorogan digunakan dalam belajar Al-Qur'an dan empat kitab lainnya yaitu, kitab fasholatan, manaqib, al-barzanzi, dan kitab dalail khairat. Metode sorogan ini termasuk belajar secara individual yang dilaksanakan dengan cara santri membaca kitab atau Al-Qur'an di hadapan guru. Hal ini berlaku bagi semua santri dalam pembelajaran baik ketika sedang suci ataupun berhalangan. Hal ini sesuai dengan pernyataan Yasin yang menyebutkan bahwa metode sorogan adalah pembelajaran kitab secara individual, dimana setiap santri menghadap secara bergiliran kepada guru untuk membaca, menjelaskan, mengulang atau menghafal pelajaran yang telah diberikan oleh guru sebelumnya. Metode sorogan merupakan metode pembelajaran dengan melibatkan santri secara langsung "individual melalui 
kegiatan membaca kitab di hadapan guru, kemudian guru mendengarkan dan menunjukkan kesalahan-kesalahannya. Maksudnya pembelajaran secara individual di mana seorang murid berhadapan dengan seorang guru terjadi interaksi saling mengenal antara keduanya (Yasin, 2008).

Selain dua metode di atas, dalam proses pembelajaran kitab atau AlQur'an, guru juga memberikan kesempatan kepada santri untuk berdiskusi. Diskusi adalah cara menyajikan bahan pelajaran melalui proses pemeriksaan dengan teliti suatu masalah tertentu dengan jalan bertukar pikiran, dan memeriksa dengan teliti mengenai berbagai hal yang terdapat didalamnya dengan jalan menguraikan, membanding-bandingkan, menilai hubungan itu, dan mengambil kesimpulan (Aqib \& Murtadlo, 2016).

Alasan mengapa dayah ini masih menggunakan metode sorogan dan bandongan karena dayah tetap ingin mempertahankan ciri khas salaf, namun tetap mengikuti zaman. Pendidikan adalah sebuah sistem yang terdiri dari beberapa komponen yang saling mendukung dalam rangka mencapai tujuan. Adapun sistem pembelajaran yang digunakan di dayah ini adalah dengan memadukan antara metode bandongan dan metode sorogan. Hal ini dilakukan agar menambah motivasi dan minat para santri dalam menuntut ilmu di dayah.

\section{Materi pembelajaran}

Materi yang diajarkan pada dayah Istiqamatuddin, Desa Lamceu adalah materi berupa sistem tersusun yang disampaikan secara klasikal. Adapun materi pembelajarannya berupa al-Qur'an, kitab tafsir jalalain, kitab nashoihul 'ibad yang didalamnya berisi tentang pendidikan akhlak, kitab dziba' yang berisi tantang kisah-kisah nabi dan sejarah nabi, kitab fasholatan tentang tata cara sholat, bersuci, mandi, kitab manakib dan kitab dalailul khairat yang berisi tentang shalawat- shalawat nabi, kitab fathul qarib yang berisi tentang pendidikan fiqih islam.

Selain itu, dayah Istiqamatuddin juga mengajarkan kitab akhlak (ta'lim muta'alim dan risalah adab sulukul murid), kitab fiqih (hasyisyah baijuri, i'anah 
thalibin, dan mahalli syarah minhaj thalibin), tafsir (tafsir jalalain hasyisyah shawi), hadits (arbain nawawi dan bulughul maram) dan nahwu (alfiah ibnu malik syarah ibnu aqil).

\section{Kendala dan Motivasi pembelajaran Selama Masa Covid-19}

Selain itu, Akhi mengungkapkan bahwa problematika yang terdapat di dayah ini dalam menghadapi masa pandemi Covid-19 adalah semakin menurunnya jumlah santri, dikarenakan sebagian santri takut dengan penyebaran Covid-19. Khususnya santri yang berasal dari Malaysia, semuanya harus kembali ke Malaysia. Selain itu, banyaknya dayah baru sehingga santri lebih memilih mengaji di dayah yang dekat dengan rumahnya.

Selama masa pandemi Covid-19, dayah tetap menjalankan proses pembelajaran dengan tetap mengikuti protokol kesehatan. Salah satu cara yang dilakukan adalah dengan membagi jadwal mengajar menjadi beberapa waktu yaitu pagi, siang, sore dan malam. Selain itu juga, santri dibagi ke dalam kelompok-kelompok kecil pengajian sehingga mencegah keramaian.

Masa pandemi Covid-19 tidak menjadi halangan berarti bagi dayah untuk melangsungkan proses pembelajaran, dikarenakan semangat guru dalam mengajar dan juga santri dalam belajar. Belajar di dayah bagi santri sangat membantu mereka mencegah kebosanan belajar daring di rumah selama masa pandemi.

Selama pembelajaran daring, peserta didik dapat menjadi kurang aktif dalam menyampaikan aspirasi dan pemikirannya, sehingga dapat mengakibatkan pembelajaran yang menjenuhkan. Seorang siswa yang mengalami kejenuhan dalam belajar akan memperoleh ketidakmajuan dalam hasil belajar. Oleh karena itu, diperlukan pendorong untuk menggerakkan siswa agar semangat belajar sehingga dapat memiliki prestasi belajar (Rimbarizki, 2017). Semangat belajar dapat dimiliki dengan meningkatkan motivasi belajar. Motivasi belajar adalah sebuah penggerak atau pendorong yang membuat seseorang akan tertarik kepada belajar sehingga akan belajar 
secara terus-menerus. Oleh karena itu, dayah Istiqamatuddin ada untuk membantu siswa (santri) agar tetap termotivasi dalam belajar sehingga kejenuhan belajar daring dapat diminimalisir. Hal tersebut dilakukan dengan menggunakan strategi, metode dan materi pembelajaran yang berbeda dengan metode daring.

\section{E. Kesimpulan}

Masa pandemi Covid-19 tidak menjadi halangan berarti bagi dayah untuk melangsungkan proses pembelajaran. Hal tersebut dikarenakan adanya semangat guru dalam mengajar dan juga santri dalam belajar. Belajar di dayah bagi santri sangat membantu mereka mencegah kebosanan belajar daring di rumah selama masa pandemi. Selama masa pandemi Covid-19, dayah tetap menjalankan proses pembelajaran dengan tetap mengikuti protokol kesehatan.

Salah satu cara yang dilakukan adalah dengan membagi jadwal mengajar menjadi beberapa waktu yaitu pagi, siang, sore dan malam. Selain itu juga, guru membagi santri ke dalam beberapa kelompok-kelompok kecil selama proses belajar, yang bertujuan untuk mencegah keramaian. Dayah dan Balai Pengajian merupakan lembaga pendidikan Islam tertua di Aceh yang telah lama berkiprah dalam membangun sumber daya manusia (SDM). Keberadaan dayah dalam konteks masa kini juga perlu dipikirkan bahwa dayah memiliki multifungsi hal-hal positif yang dapat digunakan sebagai alat dalam proses pembangunan masyarakat dan penguatan kapasitas masyarakat, seperti halnya ketika terjadi masa pandemi.

\section{Daftar Pustaka}

Ahmad., B. K. (2003). Membangun Kembali Jati Diri Ulama Aceh. Lhokseumawe: Nadiya Foundation.

Amiruddin, H. M. (2004). Eksestensi Dayah Masa Depan di Propinsi NAD. MPU Kabupaten Aceh Utara. Lhokseumawe: Nida'Al-Islam.

Aqib, Z., \& Murtadlo, A. (2016). Kumpulan Metode Pembelajaran Kreatif dan Inovatif. Bandung: Satu Nusa. 
Aurora, M. (2012, Februari 10). Retrieved from https://aceh.tribunnews.com/2012/06/07/dayah-aceh-dalamkonteks-kekinian

Azra, A. (2009). Pengantar dalam Nurhayati Djamas, Dinamika Pendidikan Islam di Indonesia Pasca kemerdekaan . Jakarta: PT.Raja Grafindo Persada.

Dhofier, Z. (2020). Tradisi Pesantren : Studi Pandangan Hidup Kyai dan Visinya Mengenai Masa Depan Indonesia. Jakarta: LP3ES.

Hamidansyah. (2011). Analisis Kebijakan Pemerintah Kabupaten Aceh Utara Dalam Pelaksanaan Pendidikan Dayah Dan Balai Pengajian. Medan: Pascasarjana UINSU.

Indonesia, D. A. (2004). Profil Pondok Pesantren Mu'adalah. Direktorat Pendidikan Keagamaan dan Pondok Pesantren, DEPAG RI.

Indonesia, K. P. (2021, Maret 2). Retrieved from https://www.kemdikbud.go.id/main/blog/2020/03/surat-edaranpencegahan -covid19-pada-satuan-pendidikan

Latif, H. M. (2007). Tradisi dan Vitalitas Dayah (Kesempatan dan Tantangan). Jurnal Didaktika, 2(8), 1.

Moleong, L. J. (2009). Metode Penelitian Kualitatif. Bandung: PT. Remaja Rosdakarya.

Poerwadarminta. (1995). Kamus Besar Bahasa Indonesia. Jakarta: Balai Pustaka.

Rahmah, S. (2009). Peran Lembaga Adat Gampong Terhadap Pelaksanaan Pendidikan Non Formal Bagi Masyarakat. Lhokseumawe: LP3M STAIN Malikussaleh.

Rimbarizki, R. (2017). Penerapan Pembelajaran Daring Kombinasi Dalam Meningkatkan Motivasi Belajar Peserta Didik Paket C Vokasi di Pusat Kegiatan Belajar Masyarakat (PKBM) Pioneer Karanganyar. 6(2).

Saby, Y. (2000). A Profile of the Ulama in Acehnese Society. Jamiah Journal Islamic Studies, 2(38), 288-289. Retrieved from A Profile of the Ulama in Acehnese Society. Jamiah Journal Islamic Studies, 2 (38): 288-289.

Shahrizal, A. (2007). Dalam Pemikiran Ulama Dayah Aceh. Jakarta: Prenada Media Group.

Sudjana, N. (2010). Cara Belajar Siswa Aktif dalam Proses Belajar Mengajar. Bandung: Sinar Baru Algensindo.

Sufi, R. (2002). Keagamaan dan Kepercayaan di Aceh pada Abad ke 19 dan ke 20. Jakarta: Yayasan Masyarakat Sejarawan Indonesia.

Undang-Undang. (2001). Undang-Undang Pemerintah Aceh No. 18 tentang Otonomi Daerah. Aceh: Pemerintah Aceh.

Yasin, F. A. (2008). Dimensi-dimensi Pendidikan Islam. Malang: UIN Malang Press.

Yurianto, A., \& Wibowo, B. (2020). Pedoman Pencegahan Dan Pengendalian Coronavirus Disease (COVID-19). 